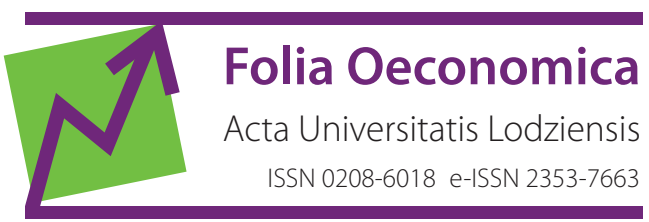

www.czasopisma.uni.lodz.pl/foe/

$1(340) 2019$

DOI: http://dx.doi.org/10.18778/0208-6018.340.06

\title{
Mateusz Jankiewicz
}

Nicolaus Copernicus University in Toruń, Faculty of Economic Sciences and Management, The Department of Applied Informatics and Mathematics in Economics

mateuszj@doktorant.umk.pl,m.jankiewicz@umk.pl

\section{The Convergence of Food Expenditures in the European Union Countries - a Spatio-Temporal Approach}

\begin{abstract}
The paper presents the analysis of the convergence of household final consumption expenditures on food in the European Union countries in the period of 1999-2015, considering spatial and spatio-temporal tendencies and dependencies. The aim of this research is to verify whether space significantly influences the convergence of the considered process. The subject of the investigation is the share of household final consumption expenditures on food in total final consumption expenditures of European countries. Spatial and spatio-temporal tendencies and dependencies are surveyed using the conception of spatial and spatio-temporal trends and spatial autocorrelation. The convergence of the process is investigated with the use of $\beta$-convergence models for panel data (also in the spatial terms). Absolute and conditional convergence approaches are applied. For the conditional approach, the models are expanded to incorporate the influence of additional determinants, including space, disposable income and the level of food prices.
\end{abstract}

Keywords: convergence, food expenditures, spatial and spatio-temporal trends, spatial autocorrelation, panel data models

JEL: C1, D1, E2 


\section{Introduction}

The article focuses on the study of the food expenditures convergence in European countries considering some determinants - income, the food prices level and spatio-temporal tendencies. The idea of the convergence process is presented by Barro and Sala-i-Martin (1992). In the following investigations, the convergence process in Europe was observed (Dall'Erba, Le Gallo, 2008; Kulhánek, 2012; Carnicky et al., 2016; von Lyncker, Thoennessen, 2017). The result of this process can be explained by the fact that the consumption structures in Europe are becoming more and more similar (Nowak, Kochkova, 2011; Jankiewicz, 2018).

Engel (1895) in his research observed the situation where the share of food expenditures fell when the income of households rose. According to Engel's law "the poorer a family, the greater the proportion of its total expenditures that must be devoted to the provision of food" (as cited in Stigler, 1954: 98). Therefore, disposable income is one of the main consumption factors.

Food expenditures have been investigated by many researchers in their papers (Banks, Blundell, Lewbel, 1997; Dudek, 2011; Dybczak, Toth, Vonka, 2014; Janský, 2014; Cupák, Pokrivčák, Rizov, 2015; Kundu, 2017). However, there are not many studies that consider spatial and spatio-temporal tendencies in the values formulation of this process. The analysis of these tendencies is a significant supplement to previous studies due to the fact that the data are spatial (values of the considered processes characterise spatial units).

The primary aim of the study is to investigate spatial and spatio-temporal tendencies of food expenditures, disposable income and the level of food prices in the European Union (excluding Croatia, Cyprus and Malta) across countries in the years 1999-2015. The second aim of the research is to analyse the convergence of food expenditures in Europe including the influence of additional determinants - disposable income and the level of food prices.

This paper provides some extension of the investigation presented in my previous work (Jankiewicz, 2018).

\section{The subject and scope of the investigation}

The study focuses on the spatial differentiation and convergence of food expenditures in the European Union countries (excluding Croatia, Cyprus and Malta) in the years 1999-2015. The following indicators have been analysed: the share of final consumption expenditures of households on food in total final consumption expenditures, disposable income per capita (in real terms) and the level of food prices. 
The adopted time range and spatial aggregation of this research allow us to see spatial and spatio-temporal tendencies in the shape of the analysed variables. These tendencies are investigated with the use of spatial and spatio-temporal models and the spatial autocorrelation approach. Moreover, spatial error models are estimated for the considered variables. The convergence of food expenditures is studied using the conception of absolute and conditional convergence. $\beta$-convergence models for panel data are estimated and verified.

The first hypothesis of the study is that food expenditures in the EU are becoming more and more similar. The second hypothesis verifies the significant influence of the additional determinants on the food expenditures convergence process.

\section{Data}

The data applied in this study come from the European Statistical Office (Eurostat) database. The share of final consumption expenditures on food in total final consumption expenditures $(Y)$ is taken directly from the database. The values of disposable income per capita $\left(X_{1}\right)$ and the food prices index $\left(X_{2}\right)$ are obtained through own calculations. The calculations and figures are made using R-Cran software (version 3.4.1), Python (version 3.5) and Gretl.

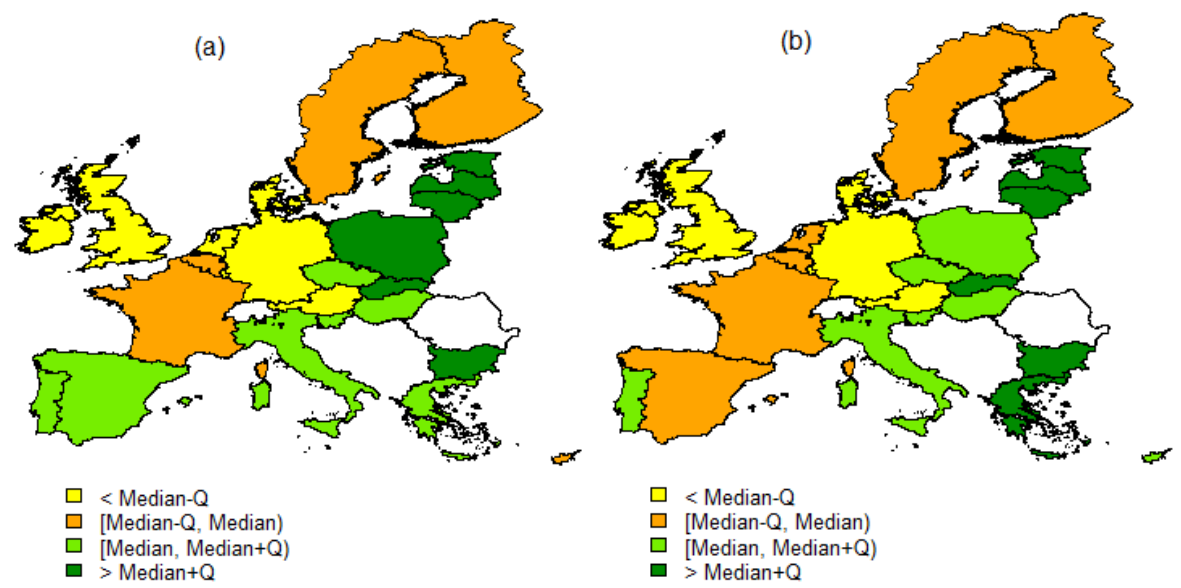

Figure 1. The share of final consumption expenditures on food in total final consumption expenditures across countries in the years 1999 (a) and 2015 (b)

Source: author's own elaboration

Figure 1 presents the spatial differentiation of variable $Y$ in the two extreme years of analysis (1999 and 2015). Figure 2 shows the trend surfaces of food expenditures for the analysed years. The northern and western part of the continent is characterised by lower values of the considered variable than the other parts. 
The eastern and southern part of Europe is dominated by relatively high values of $Y$. Moreover, the highest value of $Y$ is noted in Romania (white colour on the maps) in both years of investigation. Based on Figure 2, the presumption of presence of the second-degree spatial trend was formulated.
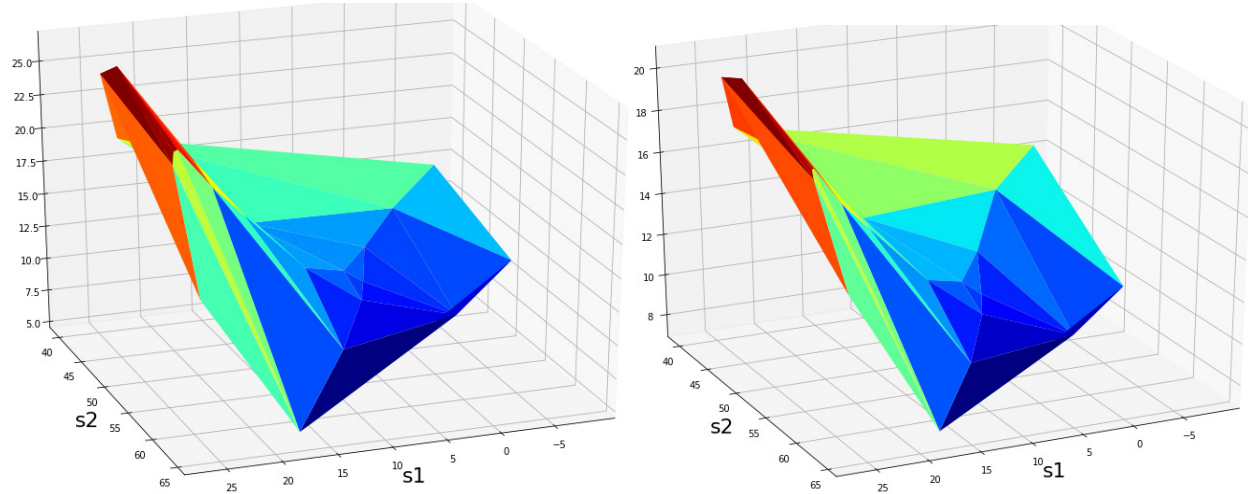

Figure 2. Trend surfaces of food expenditures across countries in the years 1999 and 2015 (s1 and s2 describe latitude and longitude)

Source: author's own elaboration
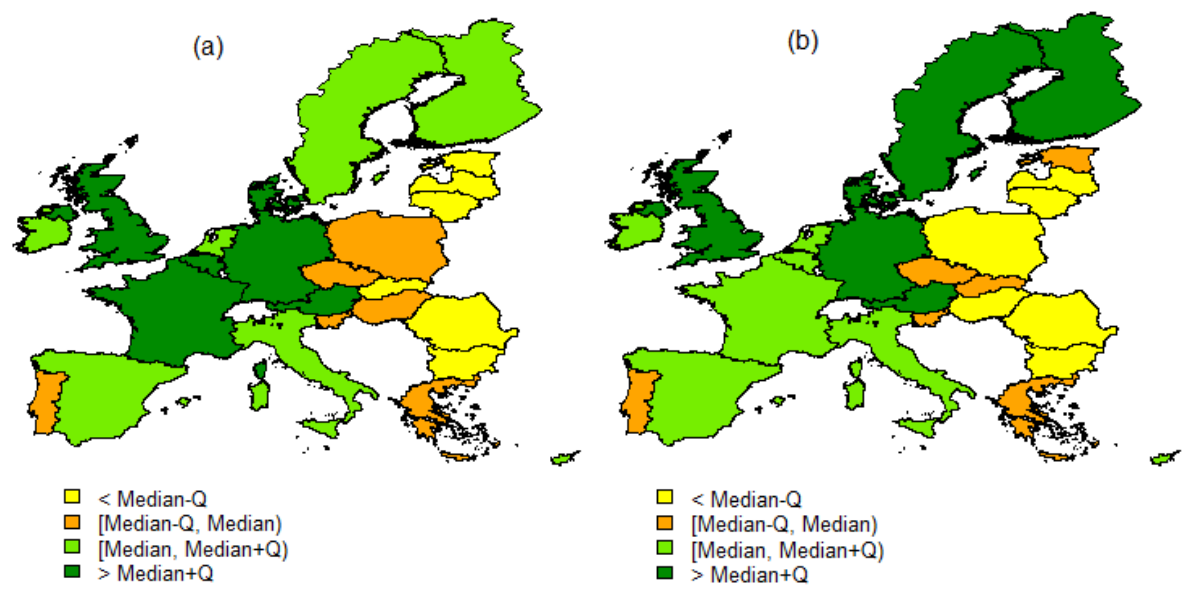

Figure 3. Disposable income per capita across countries in the years 1999 (a) and 2015 (b)

Source: author's own elaboration

Figure 3 shows the spatial differentiation of disposable income (per capita) in the European Union in the years 1999 and 2015. Figure 4 presents the trend surfaces of the considered variable for the respective years. The opposite tendency than in the previous variable in both years of investigation is noted. A high level of disposable income (more than median) is observed in the western and northern part of Europe. The central-eastern part of the continent is dominated by countries 
with a lower level of disposable income. As shown earlier, the maps in Figure 3 clearly indicate the fact that the EU is divided into two parts. The first is northern-western Europe and the other is central-eastern Europe. It is possible to suppose that the second-degree spatial trend of disposable income is observed.
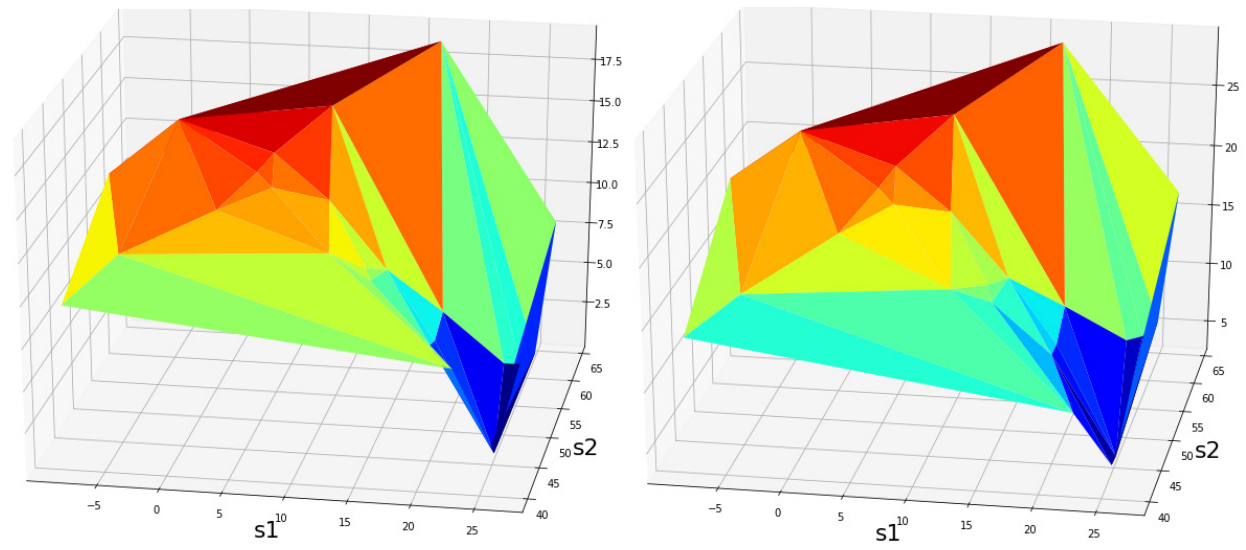

Figure 4. Trend surfaces of disposable income per capita across countries in the years 1999 and 2015 Source: author's own elaboration
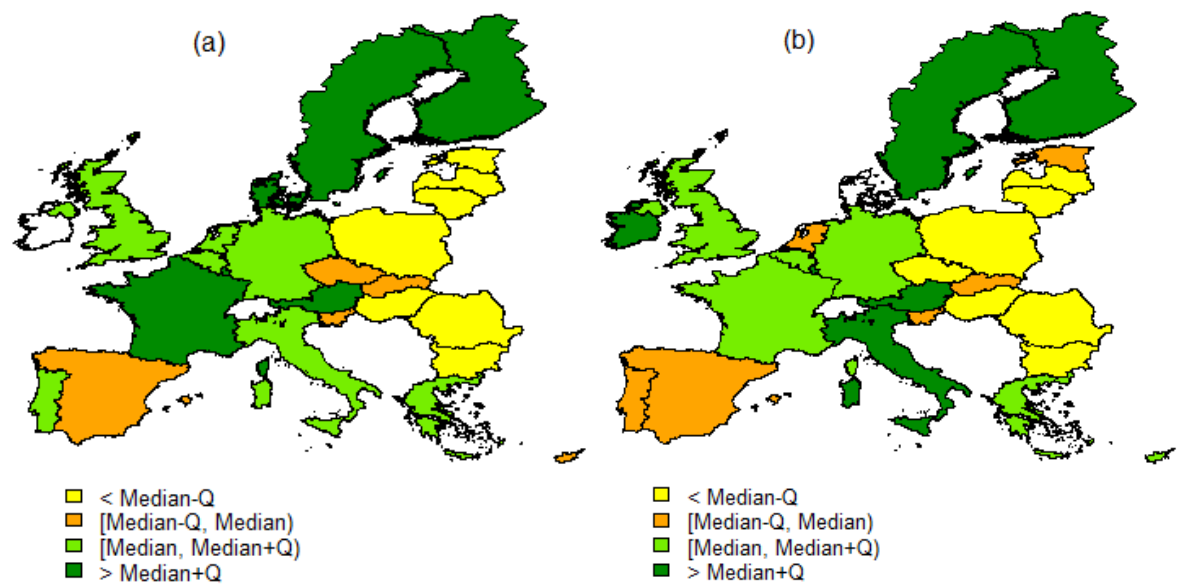

Figure 5. The food prices level across countries in the years 1999 (a) and 2015 (b) Source: author's own elaboration

In turn, Figure 5 shows the spatial differentiation of the food prices level in European countries for the same years. Figure 6 presents the trend surfaces of the considered variable for 1999 and 2015. The spatial distribution of this variable is similar and opposite to the spatial distribution of disposable income and food expenditures respectively. A high level of variable $X_{2}$ (more than median) is observed in the western, northern and southern part of Europe 
(excluding the Iberian Peninsula). The central-eastern part of the continent is dominated by countries with a lower level of food prices. As shown earlier, the maps in Figure 5 clearly indicate the fact that the EU is divided into two parts. The first is northern-western Europe and the other is central-eastern Europe. Based on Figure 6, it is possible to suppose that the second-degree spatial trend of variable $X_{2}$ is observed.
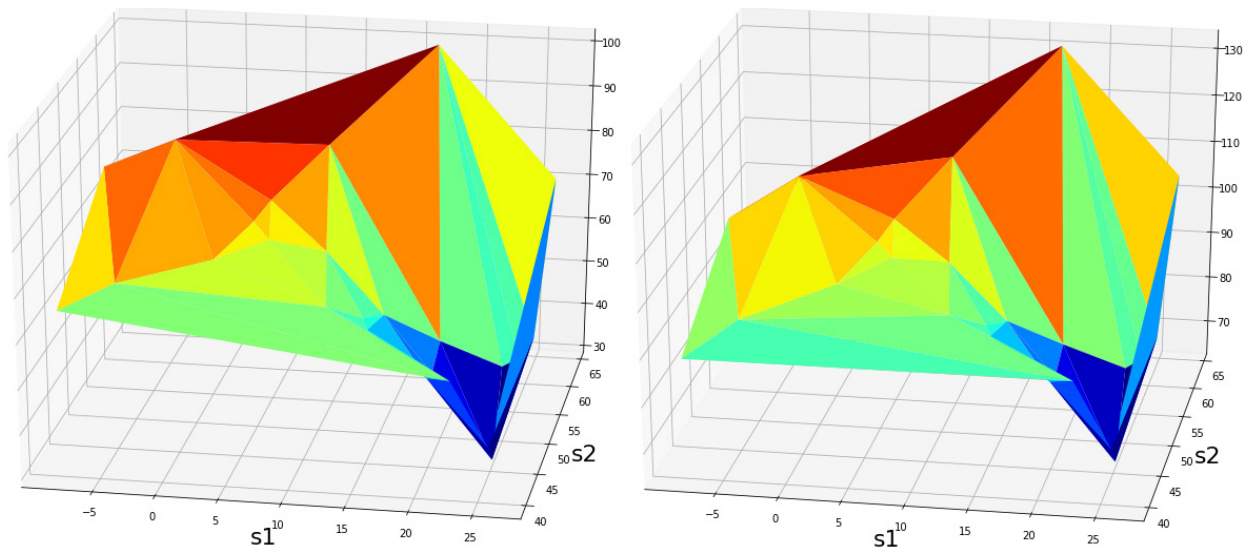

Figure 6. Trend surfaces of the food prices level across countries in the years 1999 and 2015 Source: authors' own elaboration

\section{Methodology}

\subsection{Spatio-temporal structure analysis}

The values of the analysed variables are observed in spatial units (EU countries) and in the certain time range (in the years 1999-2015). Therefore, in this study, the considered processes are treated as spatio-temporal stochastic processes. A spatio-temporal stochastic process is a random function $Y(\boldsymbol{s}, t)$, where $\boldsymbol{s}=\left[s_{1}, s_{2}\right] \in$ $D \subset R^{2}, T \in t \subset R$ are non-random arguments of the process (Cressie, 1993: 9; Schabenberger, Gotway, 2005: 432). The argument $s$ describes the locations of spatial units, and $t$ indicates time. Space and time dimensions in the study are discreet quantities, so the processes $Y\left(\boldsymbol{s}_{i}, t\right)$ are analysed, where: $\boldsymbol{s}_{i}=\left[s_{1 i}, s_{2 i}\right], i=1,2, \ldots, N$ $\subset C$, and $t=1,2, \ldots, T \subset C$ ( $C$ is the set of natural numbers). For these processes, econometric models are estimated and verified.

The first step of the study is to analyse trend-autoregressive structures of the considered variables. The models estimated at this step of the research are spatial and spatio-temporal trend models for spatial processes $Y\left(\boldsymbol{s}_{i}\right), X_{1}\left(\boldsymbol{s}_{i}\right)$ and $X_{2}\left(\boldsymbol{s}_{i}\right)$. Furthermore, spatial autocorrelation based on Moran's $I$ statistics (Moran, 1950) 
is tested and spatial error models are estimated. The form of the spatial trend model is as follows (Cressie, 1993: 155):

$$
\mu\left(s_{i}\right)=\sum \sum_{0 \leq k+m \leq p} \theta_{k, m} s_{1 i}^{k} s_{2 i}^{m}+u\left(s_{i}\right),
$$

where: $\mu\left(\boldsymbol{s}_{i}\right)$ - spatial process $\boldsymbol{s}_{i}, i$ - as above, $p$ - polynomial trend degree, $\theta_{k, m}$

- structural parameters of the model, $u\left(\boldsymbol{s}_{i}\right)$ - spatial residual process.

The form of spatio-temporal trend can be written as follows (Szulc, 2007: 103):

$$
\mu\left(s_{i}, t\right)=\sum \sum \sum_{0 \leq k+m+l \leq p} \theta_{k, m} s_{1 i}^{k} s_{2 i}^{m} t^{l}+u\left(s_{i}, t\right)
$$

where: $\boldsymbol{s}_{i}, i, p$ - as above, $t$ - indicates time, $u\left(\boldsymbol{s}_{i}, t\right)$ - spatio-temporal residual process.

Next, spatial autocorrelation was performed for each variable using the Moran test. The test statistic takes the following form (Schabenberger, Gotway, 2005: 21; Suchecki, 2010):

$$
I=\frac{1}{\sum_{i=1}^{n} \sum_{j=1}^{n} w_{i j}} * \frac{\sum_{i=1}^{n} \sum_{j=1}^{n} w_{i j}\left[y_{i}-\bar{y}\right]\left[y_{j}-\bar{y}\right]}{\frac{1}{n} \sum_{i=1}^{n}\left[y_{i}-\bar{y}\right]^{2}}=\frac{n}{S_{0}} * \frac{\boldsymbol{z}^{T} \boldsymbol{W} \boldsymbol{z}}{\boldsymbol{z}^{T} \boldsymbol{z}},
$$

where: $y_{i}-$ an observed value of the phenomenon in the region $i, \boldsymbol{z}-$ a column vector with elements $z_{i}=y_{i}-\bar{y}, S_{0}=\sum_{i=1}^{n} \sum_{j=1}^{n} w_{i j}-$ a sum of the corresponding elements of the weights matrix $\mathbf{W}, n$ - the number of regions. In this research, the matrix $\mathbf{W}$ of connections based on the common border criterion is used.

For each spatio-temporal process, the spatial error model (Anselin, Florax, Rey, 2004; Arbia, 2006) including spatio-temporal trend is estimated and verified. The model takes the form:

$$
\begin{gathered}
\mu\left(\boldsymbol{s}_{i}, t\right)=\sum \sum \sum_{0 \leq k+m+l \leq p} \theta_{k, m} s_{1 i}^{k} s_{2 i}^{m} t^{l}+u\left(\boldsymbol{s}_{i}, t\right) \\
u\left(\boldsymbol{s}_{i}, t\right)=\lambda \boldsymbol{W}^{*} u\left(\boldsymbol{s}_{i}, t\right)+\varepsilon\left(\boldsymbol{s}_{i}, t\right),
\end{gathered}
$$

where $\boldsymbol{s}_{i}, i, t, u\left(\boldsymbol{s}_{i}, t\right)$ - as above, $\varepsilon\left(\boldsymbol{s}_{i}, t\right)$ - spatio-temporal white noise. $\boldsymbol{W}^{*}$ - the block matrix of spatio-temporal connections which takes the form: 


$$
\boldsymbol{W}^{*}=\left[\begin{array}{ccc}
\boldsymbol{W}_{1} & \cdots & 0 \\
\vdots & \ddots & \vdots \\
0 & \cdots & \boldsymbol{W}_{T}
\end{array}\right],
$$

wherein: $\boldsymbol{W}_{1}=\ldots=\boldsymbol{W}_{T}$ represent standard spatial connectivity matrixes (the same for all years), such as in (3).

\subsection{Panel data and spatial panel data models}

In the next step of investigation, panel data and spatial panel data models are used for convergence process analysis (absolute and conditional). The panel and spatial panel data models for absolute convergence are estimated in the following forms (Baltagi, 2005: 13; Suchecki, 2012: 96; Kusideł, 2013: 52):

$$
\begin{gathered}
\ln \left(y_{i, t}\right)=\alpha_{0}+(1+\beta) \ln \left(y_{i, t-1}\right)+u_{i, t}, \\
\ln \left(y_{i, t}\right)=\alpha_{i}+(1+\beta) \ln \left(y_{i, t-1}\right)+u_{i, t}, \\
\ln \left(y_{i, t}\right)=\alpha_{0}+(1+\beta) \ln \left(y_{i, t-1}\right)+\eta_{i, t}, \eta_{i, t}=\lambda W\left(\eta_{i, t}\right)+u_{i, t}, \\
\ln \left(y_{i, t}\right)=\alpha_{i}+(1+\beta) \ln \left(y_{i, t-1}\right)+\eta_{i, t}, \eta_{i, t}=\lambda W\left(\eta_{i, t}\right)+u_{i, t},
\end{gathered}
$$

where: $y_{i, t}$-dependent variable $Y, \alpha_{i}$ - individual effect for $i^{\text {th }}$ spatial unit, $\eta_{i, t}, u_{i, t}$ - error component models. Models (6) and (7) are classical panel data models (pooled and fixed effects) estimated using the ordinary least squares (OLS) and least squares dummy variables (LSDV) method respectively. Models (8) and (9) are spatial error panel data models without and with fixed individual effects respectively.

The panel data and spatial panel data models for conditional convergence are estimated in the following forms (Baltagi, 2005: 13; Suchecki, 2012: 96; Kusideł, 2013: 52):

$$
\begin{aligned}
& \ln \left(y_{i, t}\right)=\alpha_{0}+(1+\beta) \ln \left(y_{i, t-1}\right)+\gamma \ln x_{1, i, t}+\delta x_{2, i, t}+\rho C R_{i, t}+u_{i, t}, \\
& \ln \left(y_{i, t}\right)=\alpha_{i}+(1+\beta) \ln \left(y_{i, t-1}\right)+\gamma \ln x_{1, i, t}+\delta x_{2, i, t}+\rho C R_{i, t}+u_{i, t},
\end{aligned}
$$




$$
\begin{gathered}
\ln \left(y_{i, t}\right)=\alpha_{0}+(1+\beta) \ln \left(y_{i, t-1}\right)+\gamma \ln x_{1, i, t}+\delta x_{2, i, t}+\rho C R_{i, t}+\eta_{i, t}, \\
\eta_{i, t}=\lambda W\left(\eta_{i, t}\right)+u_{i, t} \\
\ln \left(y_{i, t}\right)=\alpha_{0}+(1+\beta) \ln \left(y_{i, t-1}\right)+\gamma \ln x_{1, i, t}+\delta x_{2, i, t}+\rho C R_{i, t}+\eta_{i, t}, \\
\eta_{i, t}=\lambda W\left(\eta_{i, t}\right)+u_{i, t}
\end{gathered}
$$

where: $y_{i, t}, \alpha_{i}, \eta_{i, t}, u_{i, t}$ - as above, $x_{1, i, t}, x_{2, i, t}-$ natural logarithm of independent variables $X_{1}$ and $X_{2}$ respectively, $C R_{i, t}$-variable denotes financial crisis. Models (10) and (11) are estimated as models (6) and (7) respectively.

The $\beta$ parameter serves to calculate the $t_{\text {half-life }}$ value, which presents the time needed to reduce the difference by half. It is expressed as follows (Kusidel, 2013: 51):

$$
t_{\text {half-life }}=\frac{\ln (2)}{b},
$$

where: $b=-\ln (1+\beta)$ expresses the convergence rate.

\section{Specification of spatial and spatio-temporal econometric models - results of the empirical analysis}

\subsection{Analysis of spatial and spatio-temporal tendencies}

The investigation started with the analysis of the spatial tendency of the considered processes: the share of food expenditures in total final consumption expenditures $\left(Y\left(\boldsymbol{s}_{i}\right)\right)$, disposable income per capita $\left(X_{1}\left(\boldsymbol{s}_{i}\right)\right)$ and the level of food prices $\left(X_{2}\left(\boldsymbol{s}_{i}\right)\right)$. Table 1 presents the spatial structure of these processes. The spatial trend models were estimated and verified. Next, spatial autocorrelation was tested using Moran's $I$ statistics and its significance. The level of significance value 0.05 was adopted.

In each year of investigation, the presence of the spatial trend was noted for all processes. The degree of the spatial trend was fixed over all the researched period. More precisely, the second-degree spatial trend for each of the analysed variables was observed. Variable $X_{1}$ did not show spatial autocorrelation throughout the considered period. A different situation was noted for the other ones: namely for $Y$ spa- 
tial autocorrelation was noted only in three years of research (2012, 2014 and 2015), while $X_{2}$ showed significant spatial autocorrelation in the years 2000-2006. The next step of the investigation was an analysis of spatio-temporal tendencies for the considered variables. Table 2 presents the results of estimation and verification of the spatio-temporal models for the analysed variables (processes).

Table 1. Spatial structure of the processes: $Y\left(\mathbf{s}_{i}\right)$ - share of final consumption expenditures on food in total final consumption expenditures, $X_{1}\left(\boldsymbol{s}_{i}\right)$ - disposable income per capita and $X_{2}\left(\boldsymbol{s}_{i}\right)$ - food prices level

\begin{tabular}{|c|c|c|c|c|c|c|c|c|c|}
\hline \multirow[b]{2}{*}{ Year } & \multicolumn{3}{|c|}{$Y\left(s_{i}\right)$} & \multicolumn{3}{|c|}{$X_{1}\left(s_{i}\right)$} & \multicolumn{3}{|c|}{$X_{2}\left(s_{i}\right)$} \\
\hline & $\begin{array}{l}\text { Degree } \\
\text { of } \\
\text { spatial } \\
\text { trend }\end{array}$ & $\begin{array}{c}\text { Moran's } \\
I\end{array}$ & $p$-value & $\begin{array}{l}\text { Degree } \\
\text { of } \\
\text { spatial } \\
\text { trend }\end{array}$ & $\begin{array}{c}\text { Moran's } \\
I\end{array}$ & $p$-value & $\begin{array}{l}\text { Degree } \\
\text { of } \\
\text { spatial } \\
\text { trend }\end{array}$ & $\begin{array}{c}\text { Moran's } \\
I\end{array}$ & $p$-value \\
\hline 1999 & 2 & -0.2515 & \begin{tabular}{|l|}
0.1388 \\
\end{tabular} & 2 & -0.2029 & 0.1990 & 2 & -0.3598 & 0.0509 \\
\hline 2000 & 2 & -0.2713 & 0.1168 & 2 & \begin{tabular}{|l|}
-0.2064 \\
\end{tabular} & 0.1925 & 2 & \begin{tabular}{|l|}
-0.4007 \\
\end{tabular} & 0.0320 \\
\hline 2001 & 2 & -0.2454 & 0.1424 & 2 & -0.2176 & 0.1764 & 2 & -0.4475 & 0.0179 \\
\hline 2002 & 2 & -0.2901 & 0.0956 & 2 & -0.2025 & 0.1944 & 2 & -0.4814 & 0.0113 \\
\hline 2003 & 2 & -0.2702 & 0.1114 & 2 & -0.1856 & 0.2192 & 2 & -0.4929 & 0.0098 \\
\hline 2004 & 2 & -0.2355 & 0.1517 & 2 & -0.1970 & 0.2021 & 2 & -0.4748 & 0.0126 \\
\hline 2005 & 2 & -0.2461 & 0.1430 & 2 & -0.2078 & 0.1869 & 2 & -0.4441 & 0.0190 \\
\hline 2006 & 2 & -0.2305 & 0.1603 & 2 & \begin{tabular}{|l|}
-0.1996 \\
\end{tabular} & 0.1999 & 2 & -0.4138 & 0.0277 \\
\hline 2007 & 2 & -0.1806 & 0.2348 & 2 & -0.1844 & 0.2223 & 2 & -0.3350 & 0.0653 \\
\hline 2008 & 2 & -0.2662 & 0.1207 & 2 & -0.1859 & 0.2187 & 2 & -0.2441 & 0.1484 \\
\hline 2009 & 2 & -0.2768 & 0.1103 & 2 & -0.2055 & 0.1878 & 2 & -0.2113 & 0.1918 \\
\hline 2010 & 2 & -0.2750 & 0.1105 & 2 & -0.1827 & 0.2190 & 2 & -0.1440 & 0.2992 \\
\hline 2011 & 2 & -0.3395 & 0.0570 & 2 & -0.1582 & 0.2612 & 2 & -0.0996 & 0.3825 \\
\hline 2012 & 2 & -0.3533 & 0.0473 & 2 & -0.1415 & 0.2902 & 2 & -0.1168 & 0.3487 \\
\hline 2013 & 2 & -0.3426 & 0.0516 & 2 & -0.1272 & 0.3174 & 2 & -0.1162 & 0.3494 \\
\hline 2014 & 2 & -0.3885 & 0.0304 & 2 & -0.1390 & 0.2951 & 2 & -0.1026 & 0.3750 \\
\hline 2015 & 2 & -0.3755 & 0.0352 & 2 & -0.1723 & 0.2370 & 2 & -0.0850 & 0.4103 \\
\hline
\end{tabular}

Source: author's own calculations

In the case of all analysed variables, the second-degree spatio-temporal trends were noted (the same degree for spatial and temporal component). Moreover, the presence of spatial autocorrelation in the estimated models was tested. Based on the results of the Moran test, the residuals designated from these models for each of the considered variables showed spatial autocorrelation. Therefore, it was possible to estimate spatial models. Table 3 presents the results of estimation and verification of the spatial error models with the spatio-temporal trends.

The scalar parameter that measures the strength of spatial dependence $(\lambda)$ is negative and statistically significant in each of the estimated models. It means that the neighbouring countries are different in terms of factors other than the de- 
pendent variable considering only the spatial differentiation. The residuals of these models do not show spatial autocorrelation (Moran's $I$ statistics is not statistically significant).

Table 2. The results of estimation and verification of spatio-temporal trend models for the processes: $Y\left(\mathbf{s}_{i}\right), X_{1}\left(\mathbf{s}_{i}\right)$ and $X_{2}\left(\mathbf{s}_{i}\right)$

\begin{tabular}{|c|c|c|c|c|c|c|}
\hline \multirow{2}{*}{ Parameter } & \multicolumn{2}{|c|}{$\boldsymbol{Y}\left(\boldsymbol{s}_{\boldsymbol{i}}\right)$} & \multicolumn{2}{c|}{$\boldsymbol{X}_{1}\left(\boldsymbol{s}_{\boldsymbol{i}}\right)$} & \multicolumn{2}{c|}{$\boldsymbol{X}_{2}\left(\boldsymbol{s}_{\mathbf{i}}\right)$} \\
\cline { 2 - 7 } & Estimate & $\boldsymbol{p}$-value & Estimate & $\boldsymbol{p}$-value & Estimate & $\boldsymbol{p}$-value \\
\hline$\theta_{000}$ & -1.4860 & 0.0041 & 17.0000 & 0.0000 & 11.0400 & 0.0000 \\
\hline$\theta_{100}$ & -0.0541 & 0.0000 & 0.0745 & 0.0002 & 0.0350 & 0.0001 \\
\hline$\theta_{010}$ & 0.1913 & 0.0000 & -0.6250 & 0.0000 & -0.2962 & 0.0000 \\
\hline$\theta_{001}$ & -0.0232 & 0.0025 & 0.0640 & 0.0001 & 0.0297 & 0.0000 \\
\hline$\theta_{200}$ & 0.0014 & 0.0000 & -0.0037 & 0.0000 & -0.0010 & 0.0000 \\
\hline$\theta_{020}$ & -0.0023 & 0.0000 & 0.0067 & 0.0000 & 0.0032 & 0.0000 \\
\hline$\theta_{002}$ & 0.0012 & 0.0028 & -0.0025 & 0.0000 & -0.0006 & 0.1040 \\
\hline$\theta_{110}$ & 0.0011 & 0.0000 & -0.0014 & 0.0002 & -0.0008 & 0.0000 \\
\hline$\theta_{101}$ & -0.0013 & 0.0830 & 0.0017 & 0.2481 & 0.0019 & 0.0061 \\
\hline$\theta_{011}$ & 0.0000 & 0.2092 & 0.0000 & 0.9212 & 0.0000 & 0.1292 \\
\hline$R^{2}$ & \multicolumn{7}{|c|}{0.7514} & \multicolumn{2}{|c|}{0.7860} & \multicolumn{2}{c|}{0.7527} \\
\hline Moran test & $-0.2789(0.0000)$ & $-0.2782(0.0000)$ & $-0.1518(0.0011)$ \\
\hline
\end{tabular}

Source: author's own calculations

Table 3. The results of estimation and verification of the spatial error models (SEM) for the processes: $Y\left(\mathbf{s}_{i}\right), X_{1}\left(\mathbf{s}_{i}\right)$ and $X_{2}\left(\mathbf{s}_{i}\right)$

\begin{tabular}{|c|c|c|c|c|c|c|}
\hline \multirow{2}{*}{ Parameter } & \multicolumn{2}{|c|}{$\boldsymbol{Y ( { } _ { s } )}$} & \multicolumn{2}{c|}{$\boldsymbol{X 1}\left({ }_{s i}\right)$} & \multicolumn{2}{c|}{$\boldsymbol{X}\left(_{s i}\right)$} \\
\cline { 2 - 7 } & Estimate & $\boldsymbol{p}$-value & Estimate & $\boldsymbol{p}$-value & Estimate & $\boldsymbol{p}$-value \\
\hline$\theta_{000}$ & -1.7658 & 0.0000 & 16.6500 & 0.0000 & 11.0100 & 0.0000 \\
\hline$\theta_{100}$ & -0.0739 & 0.0000 & 0.0970 & 0.0000 & 0.0382 & 0.0000 \\
\hline$\theta_{010}$ & 0.2072 & 0.0000 & -0.6181 & 0.0000 & -0.2956 & 0.0000 \\
\hline$\theta_{001}$ & -0.0230 & 0.0000 & 0.0624 & 0.0000 & 0.0297 & 0.0000 \\
\hline$\theta_{200}$ & 0.0015 & 0.0000 & -0.0041 & 0.0000 & -0.0012 & 0.0000 \\
\hline$\theta_{020}$ & -0.0025 & 0.0000 & 0.0067 & 0.0000 & 0.0032 & 0.0000 \\
\hline$\theta_{002}$ & 0.0012 & 0.0000 & -0.0025 & 0.0000 & -0.0006 & 0.0425 \\
\hline$\theta_{110}$ & 0.0015 & 0.0000 & -0.0018 & 0.0000 & -0.0008 & 0.0000 \\
\hline$\theta_{101}$ & -0.0013 & 0.0049 & 0.0022 & 0.0295 & 0.0020 & 0.0003 \\
\hline$\theta_{011}$ & 0.0000 & 0.0433 & 0.0000 & 0.8126 & 0.0000 & 0.0365 \\
\hline$\lambda$ & $-0.4414(0.0000)$ & $-0.4058(0.0000)$ & $-0.2186(0.0001)$ \\
\hline Moran test & $-0.0755(0.0664)$ & $-0.0140(0.4057)$ & $-0.0109(0.4306)$ \\
\hline
\end{tabular}




\subsection{The specification of $\beta$-convergence panel data models}

After the analysis of spatial and spatio-temporal tendencies, the convergence of food expenditures was considered. For this study, $\beta$-convergence panel data models - classical and with the spatial factor - were estimated and verificated. The absolute convergence and conditional convergence approaches were used in order to conduct the research on the food expenditures convergence. Table 4 shows the results of estimation and verification of absolute $\beta$-convergence panel and spatial panel data absolute models.

Table 4. The results of estimation and verification of absolute $\beta$-convergence models for panel data

\begin{tabular}{|c|c|c|c|c|}
\hline \multirow{2}{*}{ Parameter } & \multicolumn{4}{|c|}{ Absolute Convergence } \\
\cline { 2 - 5 } & Pooled & FE_IND & SE_Pooled & SE_FE_IND \\
\hline$(1+\beta)$ & $0.9637(0.0000)$ & $0.8352(0.0000)$ & $0.9798(0.0000)$ & $0.8379(0.0000)$ \\
\hline$\lambda$ & - & - & $0.2741(0.0000)$ & $0.2732(0.0000)$ \\
\hline Wald test & $\begin{array}{c}F=2.5296, \\
p \text {-value }=0.0001\end{array}$ & - & $\begin{array}{c}F=3.3035, \\
p \text {-value }=0.0010\end{array}$ & - \\
\hline Moran test & - & - & $-0.0439(0.2037)$ & $-0.0384(0.2365)$ \\
\hline $\begin{array}{c}\text { Speed } \\
\text { of conver- } \\
\text { gence }\end{array}$ & 0.0370 & 0.2416 & 0.0205 & 0.1769 \\
\hline$t_{\text {half-life }}$ & 18.7213 & 2.8688 & 33.8860 & 3.9181 \\
\hline
\end{tabular}

Source: author's own calculations

Four types of panel data models were estimated: OLS model (Pooled), fixed individual effect model (FE_IND), spatial error panel data model (SE_Pooled) and spatial error panel data model with fixed individual effects (SE_FE_IND). The parameter referring to the time-lagged dependent variable $(1+\beta)$ is positive and statistically significant. Based on the Wald test, the fixed effects in convergence analysis are also significant. The spatial factor influences the convergence process - the parameter $\lambda$ is statistically significant. It means that the conditions in neighbouring countries impact food expenditures in a specific country. The residuals of the spatial error models do not indicate spatial autocorrelation. According to the pooled model model, approx. 19 years are needed to reduce inequalities in food expenditures by half. Based on the FE_INDmodel, this time is much shorter - less than 3 years. In models with the impact of the spatial factor, the half-life time lengthens to approx. 3 and 4 years respectively.

Expanding the models by including the influence of disposable income per capita, the level of food prices and the crisis variable on consumers food expenditures, the conditional convergence was analysed. Table 5 presents the results of estimation and verification of panel data conditional $\beta$-convergence models (also in the spatial terms). The significance and positive sign of the parameter $(1+\beta)$ 
(reflecting the influence of the time-lagged dependent variable) shows that the convergence process occurs. Moreover, influences of disposable income (parameter $\gamma$ ), the level of food prices (parameter $\delta$ ) and the financial crisis (parameter $\rho$ ) are also significant (excluding the parameters $\gamma$ and $\delta$ in Pooled and SE_Pooled models). Again, the Wald test shows significance of the fixed effects and the residuals of the SE_Pooled odn SE_FE_IND models do not show spatial autocorrelation. Time needed to reduce inequalities in food expenditures by half calculated in line with FE_IND and SE_FE_IND models is shorter than calculated from pooled models. Moreover, for these models (excluding SE_Pooled), the half-life is shorter considering conditional convergence, not absolute convergence.

Table 5. The results of estimation and verification of conditional $\beta$-convergence models for panel data

\begin{tabular}{|c|c|c|c|c|}
\hline \multirow{2}{*}{ Parameter } & \multicolumn{4}{|c|}{ Conditional Convergence } \\
\cline { 2 - 5 } & Pooled & FE_IND & SE_Pooled & SE_FE_IND \\
\hline$(1+\beta)$ & $0.9588(0.0000)$ & $0.6640(0.0000)$ & $0.9987(0.0000)$ & $0.8179(0.0000)$ \\
\hline$\gamma$ & $-0.0140(0.1283)$ & $-0.1021(0.0000)$ & $0.0072(0.2081)$ & $-0.0351(0.0048)$ \\
\hline$\delta$ & $0.0283(0.0868)$ & $0.1289(0.0000)$ & $0.0090(0.3704)$ & $0.0492(0.0027)$ \\
\hline$\rho$ & $0.0168(0.0001)$ & $0.0141(0.0005)$ & $0.0155(0.0008)$ & $0.0097(0.0261)$ \\
\hline$\lambda$ & - & - & $0.2408(0.0000)$ & $0.2278(0.0000)$ \\
\hline Wald test & $\begin{array}{c}F=4.1204, \\
\text {-value }=0.0000\end{array}$ & - & $\begin{array}{c}F=3.4011, \\
p \text {-value }=0.0004\end{array}$ & - \\
\hline Moran test & - & - & $-0.0331(0.2704)$ & $-0.0300(0.2913)$ \\
\hline $\begin{array}{c}\text { Speed } \\
\text { of conver- } \\
\text { gence }\end{array}$ & 0.0420252 & 0.4095 & 0.0013 & 0.2010 \\
\hline$t_{\text {half-life }}$ & 16.493601 & 1.6926 & & 3.4479 \\
\hline
\end{tabular}

Source: author's own calculations

\section{Conclusions}

The analysis showed that spatial and spatio-temporal dependencies are observable in all of the considered processes: food expenditures, disposable income and the level of food prices in Europe. The eastern part of the continent is dominated by countries with a relatively high level of the share of households expenditures on food in total expenditures. Moreover, these countries are characterised by a lower level of disposable income than the others, wherein the food is cheaper than in the southern-western part of Europe.

Based on the study, it was concluded that the convergence process of food expenditures in Europe is progressive. Simultaneously, the influence of disposable 
income and the level of food prices significantly shorten the time to reduce inequalities in the considered process. It was possible to suppose that those determinants would interact in the similar way in the considered expenditures, however, the models showed the opposite impact (parameters with negative and positive sign respectively). The increase of the level of food prices causes the decrease of the real wages. Therefore, households can consume fewer other goods and the share of food expenditures in the final consumption expenditures increases. The influence of changes in the food price level can vary in different countries. It can be a result of their level of development. In further research, the countries will be divided into highly and poorly developed. The financial crisis had a significant impact on food expenditures - the share of food expenditures in total consumption expenditures was higher in the time of crisis.

In the next step of research, the convergence models should be extended to include the influence of additional determinants: consumer credits as well as demographic and technological conditions in European countries. $\beta$-convergence models could be estimated for central-eastern and southern-western countries separately. Furthermore, an analysis of the $\sigma$-convergence and $\gamma$-convergence could be a valuable supplement to the food expenditures convergence.

\section{References}

Anselin L., Florax R.J.G.M., Rey S. (2004), Advances in Spatial Econometrics. Methodology, Tools and Applications, Springer-Verlag, New York.

Arbia G. (2006), Spatial Econometrics. Statistical Foundations and Applications to Regional Convergence, Springer-Verlag, Berlin-Heidelberg.

Baltagi B. (2005), Econometric analysis of panel data, John Wiley \& Sons Ltd, Chichester.

Banks J., Blundell R., Lewbel A. (1997), Quadratic Engel curves and consumer demand, "Review of Economics and Statistics", vol. 79, issue 4, pp. 527-539.

Barro R.J., Sala-i-Martin X. (1992), Convergence, "Journal of Political Economy”, vol. 100, issue 2, pp. 223-251.

Carnicky S., Megyesiova S., Conkova M., Zavadsky C. (2016), Productivity development and convergence across the EU Member States, “Економічний часопис-XXI”, vol. 162, issue 11-12, pp. 13-17.

Cressie N.A.C. (1993), Statistics for Spatial Data, John Wiley \& Sons Inc., New York.

Cupák A., Pokrivčák J., Rizov M. (2015), Food demand and consumption patterns in the new EU member states: the case of Slovakia, "Ekonomickýčasopis", vol. 63, issue 4, pp. 339-358.

Dall'Erba S., Le Gallo J. (2008), Regional convergence and the impact of European structural funds over 1989-1999: A spatial econometric analysis, "Papers in Regional Science", vol. 87, issue 2, pp. 219-244.

Dudek H. (2011), Quantitativeanalysis of the household's expenditure for food, "Zeszyty Naukowe Szkoły Głównej Gospodarstwa Wiejskiego w Warszawie. Problemy Rolnictwa Światowego”, no. 11(3), pp. 23-30.

Dybczak K., Toth P., Vonka D. (2014), Effects of Price Shocks to Consumer Demand. Estimating the QUAIDS Demand System on Czech Household Budget Survey Data, "Czech Journal of Economics and Finance", vol. 64, issue 6, pp. 476-500. 
Engel E. (1895), Die Lebenskosten Belgischer Arbeiter-Familien Fruher und Jetzt, "International Statistical Institute Bulletin”, vol. 9, pp. 1-74.

Jankiewicz M. (2018), The Influence of the Disposable Income on the Consumption Structure in European Countries - Spatio-Temporal Analysis, Proceedings of the $4^{\text {th }}$ International Conference on European Integration 2018, Ostrava.

Janský P. (2014), Consumer demand system estimation and value added tax reforms in the Czech Republic, IES Working Paper, No. 07/2014.

Kulhánek L. (2012), Real Convergence in Central European EU Member States, International Conference on European Integration, VŠB-TU Ostrava, Faculty of Economics, Ostrava.

Kundu S. (2017), Consumption Pattern in West Bengal - A Study of Per Capita Expenditure Elasticity by Income Group, "Journal of Economic \& Social Development", vol. 13, issue 1, pp. 1-6.

Kusideł E. (2013), Konwergencja gospodarcza w Polsce, Wydawnictwo Uniwersytetu Łódzkiego, Łódź.

Lyncker K. von, Thoennessen R. (2017), Regional club convergence in the EU: evidence from a panel data analysis, "Empirical Economics", vol. 52, issue 2, pp. 525-553.

Moran P.A.P. (1950), The Interpretation of Statistical Maps, "Journal of the Royal Statistical Society", Series B, vol. 10, pp. 243-251.

Nowak J., Kochkova O. (2011), Income, Culture, and Household Consumption Expenditure Patterns in the European Union: Convergence or Divergence?, "Journal of International Consumer Marketing", vol. 23, issue 3-4, pp. 260-275.

Schabenberger O., Gotway C.A. (2005), Statistical Methods for Spatial Data Analysis, Chapman \& Hall/CRC, Boca Raton-London-New York.

Stigler G.J. (1954), The early history of empirical studies of consumer behaviour, "Journal of Political Economy", vol. 62, issue 2, pp. 95-113.

Suchecki B. (ed.). (2010), Ekonometria przestrzenna: metody i modele analizy danych przestrzennych, C.H. Beck, Warszawa.

Suchecki B. (ed.). (2012), Ekonometria przestrzenna II: modele zaawansowane, C.H. Beck, Warszawa.

Szulc E. (2007), Ekonometryczna analiza wielowymiarowych procesów gospodarczych (Econometric Analysis of Multidimensional Economic Processes), Uniwersytet Mikołaja Kopernika, Torun.

\section{Konwergencja wydatków na żywność w krajach Unii Europejskiej - analiza przestrzenno-czasowa}

Streszczenie: Artykuł prezentuje analizę konwergencji finalnych wydatków gospodarstw domowych na konsumpcję żywności w krajach Unii Europejskiej w latach 1999-2015, uwzględniając tendencje i zależności przestrzenne oraz przestrzenno-czasowe. Celem badania jest sprawdzenie, czy aspekt zróżnicowania przestrzennego istotnie wpływa na proces konwergencji tych wydatków. Przedmiotem badania jest udział wydatków gospodarstw domowych na żywność w wydatkach ogółem tych gospodarstw w krajach europejskich. Przestrzenne i przestrzenno-czasowe tendencje i zależności są badane z wykorzystaniem koncepcji modeli trendu przestrzennego i przestrzenno-czasowego oraz autokorelacji przestrzennej. Modele $\beta$-konwergencji dla danych panelowych (również w ujęciu przestrzennym) służą wyjaśnieniu procesu konwergencji wydatków na żywność. Rozważane są dwa podejścia do analizy konwergencji - konwergencja absolutna oraz konwergencja warunkowa. W przypadku tej drugiej modele są rozszerzone o działanie dodatkowych determinant analizowanego procesu - dochodu rozporządzalnego oraz poziomu cen żywności. 
Słowa kluczowe: konwergencja, wydatki na żywność, trend przestrzenny i przestrzenno-czasowy, autokorelacja przestrzenna, modele danych panelowych

JEL: C1, D1, E2

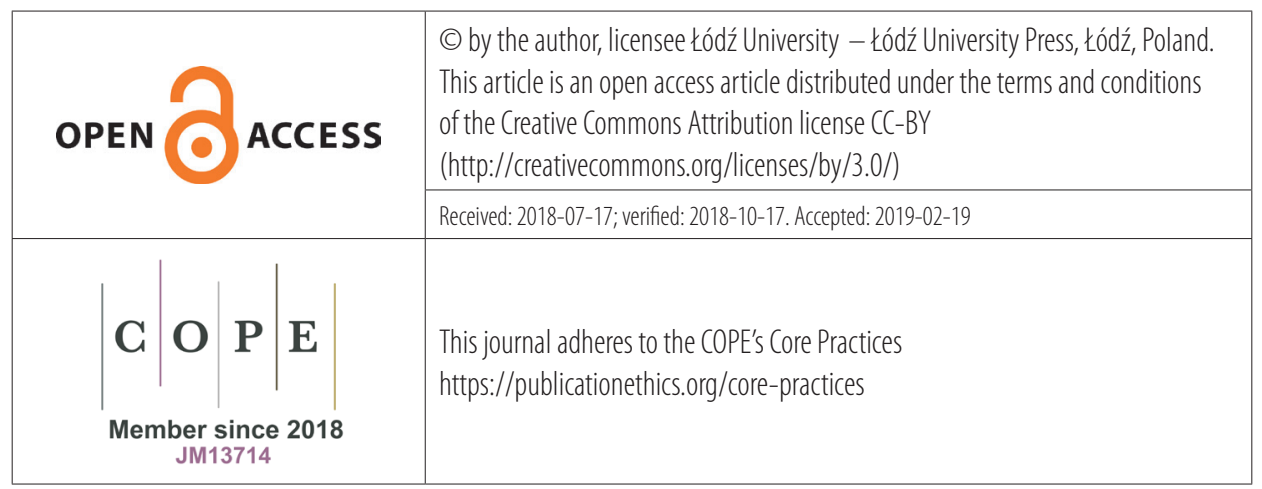

